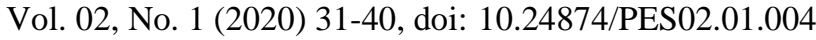 \\ Proceedings on Engineering Sciences
}

\section{THE EFFECT OF MANAGEMENT (STYLE) ON COST OF QUALITY IN ENGINEERING PROJECTS}

\author{
Hamza Ali. K. Krebish ${ }^{1}$ \\ Aysen Berberoglu
}

Keywords:

Construction projects; Management style; Quality cost management; Cost of quality; Libya.

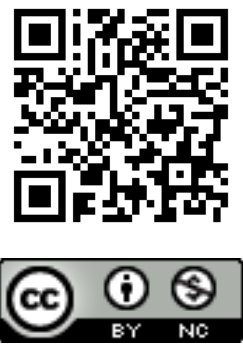

A B S T R A C T

Management styles affect quality cost in the construction industry. Despite this, little has been done to counter the negative effects. This study investigated the relationship between management styles and the cost of quality in the construction industry using self-administered questionnaires distributed among employees of two different construction firms in Libya, Tripoli state. Moreover, literature review was carried out from different books, journals and articles to arrive at the intention. The findings of the questionnaire reveal that indeed management styles have an impact on the cost of quality. Thus, there a need for construction firms to adopt cost of quality, but most importantly have an effective leadership that will support them to take up cost quality and implement it to achieve company objectives and those of their clients.

(C) 2020 Published by Faculty of Engineering

\section{INTRODUCTION}

Recently, there's been a raising interest and requirement for attractive management systems in the construction and manufacturing industries. To cut on costs and maximize on profits, several firms have factored in effective and efficient quality management styles. However, due to operational and attitudinal barriers, there has been a slow uptake.

Management styles in the engineering sector affect the quality and cost of projects. As such, firms should adopt a style that promotes quality, reduces cost and guarantees profits.

Every manager or leader in a firm has an operarting style which affects how things are done. One's managment style is a reflection of their basic philosophy regarding how tasks should be accomplished (Schmidt \& Rieck,

\footnotetext{
${ }^{1}$ Corresponding author: Hamza Ali. K. Krebish Email: Ang.ly80@yahoo.com

2000). Style refers to how a manager employs this philosophy in the workplace.

There are different management styles including autocratic, paternalistic, democratic, participatory, supervisory etc. A particular style might be more suitable for a certain type of business or employee group than another. As a whole, a management style in an organization can be defined as a leadership method used by a firm or business in carrying out its operations including managing its employees to achieve the highest degree of effectiveness.

This research works to investigate the effect of these management styles on the cost of quality in the construction industry in Tripoli state, Libya.

In their research, Hokoma et al. (2008) found that Libya's industrial companies suffered major difficulties due to operational and managerial challenges. At the time, according to the study, Libya's industrial firms operated 
at about $50 \%$ of their overall capacity. The findings added to other studies that showed that both private and public companies in Libya did not invest in research and lacked proper administrative skills.

Although recent studies on firms dealing in iron, steel, cement, oil and gas in Libya show that that they are implementing total quality management (TQM) principles, the adoption rate is still very low.

In the 1900s for example, quality management was set around good craftsmanship and workmanship. The masters usually set the pace for good workmanship.

The role of TQM is key to the success of a business. Needless to say, statistical analysis prove that organization action rely totally on management action. That means if the management action changes, transformation of an organization action is possible. In the same way, TQM has a direct effect on management of an organization leading to better output (products and services).

Thus, TQM can be defined as the skill set of the whole management in a bid to gain excellence. In other words, TQM can also be defined as the process of consecutively improving an organization. The techniques of TQM especially human resources provide an opportunity to improve an organization as well as deliver customer satisfaction.

Under TQM techniques it is possible to approach success in management of an organization and quality of products in a disciplined way.

Failure to utilize quality cost systems results into inadequate performances. According to Khattak and Ashrad (2015) top management can hinder implementation of quality management systems. Often, this results in inefficiency and as Madsen (2013) observes, it consequently leads to poor projects. To counter this, Hokoma et al. (2008) encourage firms to use information on quality costs towards the inquiry of performance deficiency.

In Zhou (2006) and O'Neill et al. (2016), most successful companies utilize total quality management strategies. In contrast, Neyestani and Juanzon (2016) argue that project success is different for every industry and as such, success is defined differently by each sector or company.

In a research, Kerzner (2010) argues that irrespective of industry, a project is dubbed successful when primary and secondary factors are satisfied. Primary factors include observing the set timelines, working within a budget, and the attainment of highest degree of quality. Secondary factors on the other hand include customer satisfaction. The iron triangle best describes Kerzner's view point (figure 1).
Although Enshassi et al. (2014) do not disagree with Kerzner's definition of project success, they reveal other vital factors that must be met for the success of a project. According to them, these elements are cost, time, quality, project efficiency, owner's satisfaction, project effectiveness, safety, risk, HR, communication, procurements, and environment.

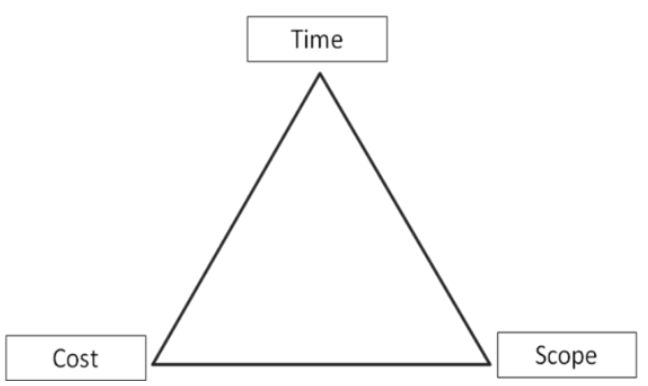

Figure 1. Iron Triangle - The reflection of organization objectives

Rasmy (2008) observes that time, cost, and customer's requirements must be met for the achievement of project success.

In a futuristic view Perkowski (1988) noted that the characteristics of successful engineering and construction companies in years to come will be as follows:

- understand change

- adopt a systems approach

- accept mistakes happen and reward sensible risk-taking; and

- provide innovative services.

Ali and Rahmat (2010) as quoted by Mane and Patil (2015) observe that most project managers hardly concentrate on project quality. In his study, Alberto (2011) notes that in most construction projects, quality is a general philosophy where processes are carried out in a general quality infrastructure. On the other hand, Aized (2012) proposes that a quality management system is an inclusive and systemic approach that includes guidance, documentation and audit such as in the ISO 9001 guidelines.

In essence, achieving quality is not expensive, rather nonadherence to quality is. Unfortunately, most companies today are often handling the costs that come with the nonachievement of quality. By so doing, companies are condoning this behaviour by allowing project planners and managers to downplay quality leading to a form of resistance to management measures, such as total quality management. This is especially true in the location of this case study, Libya.

As observed by Rahnamayroodposhti (2008) quality is achieved when a product or service is able to affect a customer's buying decision and satisfies the need it was purchased for. Thus, if a product meets a cutsomer's 
expectations, it is considered of high quality. On the other hand, if the need (satisfaction) is not fulfilled, the product may be lablled 'low quality'. In short, quality is defined as the ability of a product to fulfill customer's expectations and needs.

Given the previous definitions of 'quality' and 'managemtn' we an thus, say that quality management is about utilizing available resources within a reasonable time frame, at a worthy cost and minimal risk to provide customer satisfaction and expecattions. It is important for the management to have a long-term dedication to quality assurance and a consistent improvement pattern if merits and benefits are to be accomplished.

\subsection{Basic TQM principles}

Seven basic principles of TQM are:

- The top management of an organization will be responsible for quality of product.

- $\quad$ The product quality should only be judged by customers.

- The working procedures should be designed in such a way that high-quality goods can be produced.

- The workers should realize that it's their responsibility produce high quality products.

- The special inspection of quality in a product is the first step and should be given priority.

- The monitoring process of the quality product is also very important.

- The company or an organization should continuously strive to achieve the goal of improving quality of products.

Under these seven basic principles of TQM it is possible to achieve success in management of an organization and improve quality of products.

One major setback in the implementation of TQM is awareness. Most organizations become aware of the need for TQM when they experience losses.

However, the best approach would be for firms to engage strategies to improve product quality, at all times.

Traditionally, cost is the price of creating goods and services. For an organisation to be termed as effecient, it should be able to achieve its set goals within the smallest possible expenditure. Quality cost is thus the ability of an organization to utilize its resources (input) to achieve products (output) within the lowest cost (Hilton et al., 2008).

Quality cost is the related costs that prevent an organization from suffering losses through product defects. Costs associated with defects and incompetent projects can be very damaging to a firm.

Often, quality management tools are treated as problem solving kits, instead, they should be incorporated as a means of operations in the production, in this case, construction process. By so doing, construction projects will be more satisfying both to the client and the construction/engineering firm.

\subsection{Categories of cost of quality}

Quality cost falls into four categories: prevention cost, appraisal cost, internal failure cost and external failure cost. According to Ross (1999) Prevention cost is put in place to prevent poor product quality. It includes the prevention of defects from occuring and to keep the cost of appraisal and failure to a bare minimum. These costs might be incurred through product reviews, supplier surveys, education and training as well as quality planning among others.

Appraisal cost is put in place to detect the problems in the quality of the product (it involves measuring, evaluating or auditing) to assure quality conformance. A good example of apparisal cost include inspection of products, service audits, receipt inspection etc. Internal failure cost is the cost incurred before a product reaches the customers. It includes all costs incured when reinspecting, re-testing, or redesigning products before they reach the end user. Further, external failure cost is such failure that arises after customers receive the products. External failure is associated with processing customer complaints, warranty claims, product recalls, or customer returns (Zimak, 2000). Over and above, total cost of quality is the sum of all these costs that affect the production process.

According to the ISO 8402 'quality improvement' is defined as actions taken within the entire organization to enhance the effectiveness and efficiency of activities and other processes as to provide all the added merits to the organization and their customers.

A common and general challenge faced by many project planners in the construction industry is inadequate resources for the attainment of quality.

According to Fan et al. (2008) project management is the act of planning, channelling and controlling available resources in order to attain specific set goals and project objectives.

Afshar et al. (2007) observes that the integral aspect of project management is information associated with the maximum balance of the project objectives.

Most companies take quality management as a means to meet clients' satisfaction only. A typical example of this scenario is seen in a study that was carried out by Caldwell and Hagen (1994) where he examined the principal factors that influenced the conventional practices of quality in the United States of America. It was discovered that the commercial and outright assumption in companies and organizations that offered 
services was the notion that quality is fulfilling the requirements of a client.

While achieving client satisfaction is necessary, minimizing the firm's costs to the lowest possible rate while maintaining quality is also essential. The two aspects should thus be targeted concurrently.

To improve quality, Vaxevanidis and Petropoulos, (2008) advise organizations to consider costs associated with attaining quality as the objective of continous improvement plans is not only to satisty customer's expectations, but to do it at the lowest cost possible.

Quality cost is best used as a way to handle failure either perceived or actual. It should be considered from the inception to the completion of projects.

Therefore, it is safe to conclude that an increase in the costs of prevention leads to reduction in the cost of failure as indicated in figure 2.

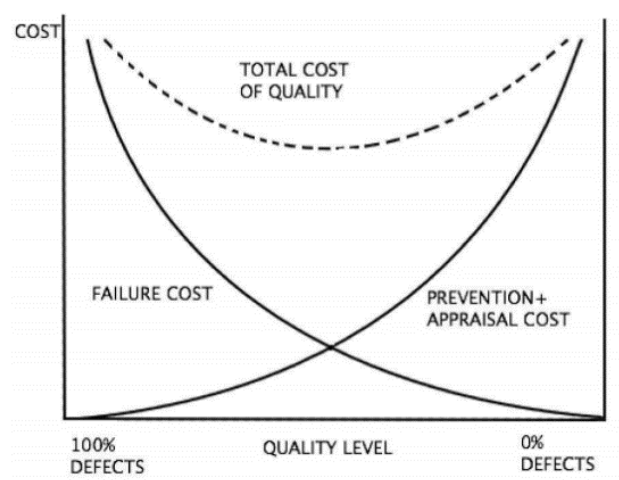

Figure 2. Cost and Quality level, according to PAF model

(Source: Kazaz, et al, 2005)

\subsection{Quality Managment System (QMS)}

In pursuit of quality, organisations should have a well defined system to satisfy the needs of all stakeholders including internal and end users (customers).

Companies executing QMS normally have planned and documented procedures that are followed to meet the set expectations. ISO 9001- the interantional quality standrad- outline the requirments of quality managment system contantly satisfy customer expectations and the set statutory regulations (Natarajan, 2017).

Generally, 9001 QMS processes are divided into four steps: Plan, Do, Check, and Act (PDCA) cycle. For the purposes of meeting the expectations of the customer and employees, firms must establish procedures and product engineering documents.
In the cosntruction industry an ideal and comprehensive quality management system is that system which is independent of simple control and inspection methods but instead is a complete system, which comprises of the following:

- System document used in recording pass or fail

- Confirmation when faults or damages are restored

- Safe, suitable and highly efficient equipment's

- Clear communication of instructions to everyone.

- Training which aids in rendering skills and necessary abilities.

- Adequate site working condition and sufficient inspection

- Functional authority with the power to correct faults

- Motivation for quality production

- Proper records for checking and testing of completed works.

\section{PRESENT INVESTIGATION}

The last few decades have seen a considerable paradigm shift in improving the quality of products in different industries, thanks to the Total Quality Management (TQM) gurus such as Juran, Deming, Crosby and Feigenbaum. Through their TQM theories, firms have realised the importance of improving business quality in the 20th Century.

Deming (1986) developed a systematic approach to problem solving known as Plan, Do, Check, Act (PDCA) cycle (figure 3). While Crosby (1979) popularised the Cost of Quality concept, Feigenbaum (1991) is famed for defining 'Total Quality' as a system that integrates quality-development, quality-maintenance, and qualityimprovement of the different departments in an organisation for purposes of marketing, engineering, production and service in geared towards customer satisfaction.

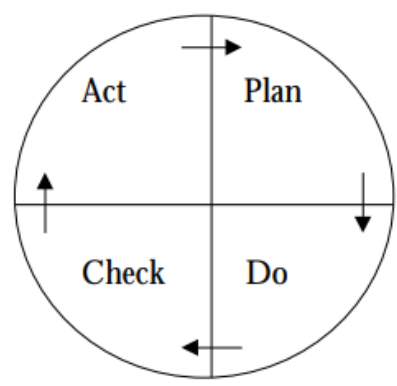

Figure 3. The improvement Cycle (Source: Deming, 1986)

The main role of TQM is to meet custmer's expectations while remaining competive. By their very presence in an organisation, qualiy managment system improves the level of quality awareness across all departments. 
Consequently, this impacts positively the general behaviour towards quality assurance amongst company's employees.

The second function is to provide certification. This is a process whereby products and processes are certified so as to equip the organization with competitive advantage in today's global business space which has become very quality conscious.

In this study, we addressed the question whether management style in a given organization has any effect on quality cost of a construction project.

Specifically we asked: "What effect do managerial styles have on the cost of quality in construction or civil engineering projects?

This study is motivated by Dr. Armand Feigenbaum's notion that most companies operate without the knowledge of what things cost.

In an interview dubbed 'Dr. Armand Feigenbaum on the Cost of Quality and the Hidden Factory' Feigenbaum notes that "many decisions with respect to what is the best way to go for business or quality improvement are made incorrectly" (Stevens, 1994).

He observed that traditional cost accounting fails to pick on the fact that quality cost deals with delivering customer satisfaction effectively. In particular, like Feigenbaum's concept, the paper arrives at the conclusion that cost of quality is not only about dealing with the cost of getting it right, but also the cost of failing to get it right.

The costs of getting it right and getting it wrong is majorly affected by the management styles employed in a given firm. Even with the best management systems, Ross (1999) notes that solely depending on them for total quality management implementation is like "straightening the deck chairs on the Titanic".

This is to say, that the achievement of cost of quality involves not only a good quality management system but also effective leadership to educate and communicate the necessary information right from the market research department to customer service.

To capture the ideal settings and operational plans of the two identified construction firms in Libya questionnaires are distributed among company employees including the managers, consultants, contractors, engineers, surveyor, and architectures.

\section{METHODOLOGY}

Data collection methods are categorised into primary and secondary. Several researchers begin research process by analyzing previous data that has already been analyzed and were obtained for other uses, this is usually done as starting point and as guide to answer and tailor the research questions of the study, aims and objectives as well as support the study with literatures and appropriate references. This is termed as secondary data collection method. The research then moves to the actual work of obtaining new data on the particular study at hand in this case using the primary data collection method.

For the purpose of this research study, both primary and secondary data collection methods were used in conducting the research. The primary method was used to record the implementation process of management styles as related to the cost of quality in the two construction firm. Cost drivers within the organization and perception of all the respondents are studied intensively so as to identify their various needs and expectations, thus meeting the set out objectives.

The present investigation worked with employees from two firms in Libya, namely: Misrat Cement factory, and Dana Libyan Korean construction companies.

The study seeks to establish the relationship between management style and its effects on cost of quality. After careful analysis of previous studies, the questionnaire was drafted to obtain data from the two construction firms with over 350 employees in total. The questionnaires were self-distributed considering available resources, time frame and nature of the study. The study worked with the following hypothesis:

- H1: use of cost of quality concept improves the management (style).

- H1.1: implementation of quality does not affect the cost of quality.

- H1.2: use of management of quality does not show a positive effect on the cost of quality.

\subsection{Data collection}

180 questionnaires were distributed among the participants who included managers and other employees working in construction departments. The two companies had approximately 350 employees in total which led to $7 \%$ margin of error and $90 \%$ confidence level when 101 questionnaires were taken as the sample size of the study. Further, journals and articles and other secondary sources were used to further gather information on the topic under investigation.

\subsection{The questionnaire}

The questionnaire is divided into three sections to capture essential and suitable data. The first section captures the respondent's basic information making it a quantitative analysis. The other two sections are designed to analyze the degree to which a participant agrees or disagrees with a question, thus it's a qualitative analysis.

The questions are related to the effect of leadership style on cost of quality in engineering projects. The 
questionnaire contains closed ended questions. Respondents give answers to the questions by either ticking the correct answer or identifying the most suitable number using a five point Likert rating scale. To maintain confidentiality and anonymity of the respondents, they were not required to give their names or any information that would identify them.

The results from the questionnaires are carefully examined, assessed to ensure they capture the reality on the ground.

\section{MEASURES}

The respondents' age, gender, marital status, education level and job position were assessed in the first section of the study (Table 1 and 2).

Table 1. Respndent's basic information

\begin{tabular}{|c|c|c|c|}
\hline Variable & Frequency & $\%$ Percentage & Cumulative percentage \\
\hline $\begin{array}{c}\text { Gender } \\
\text { Female }\end{array}$ & 17 & $16.8 \%$ & $83.2 \%$ \\
\hline Male & 84 & $83.2 \%$ & $83.2 \%$ \\
\hline $\begin{array}{c}\text { Age group } \\
20-25\end{array}$ & 32 & $31.7 \%$ & $31.7 \%$ \\
\hline $26-30$ & 36 & $35.6 \%$ & $67.3 \%$ \\
\hline $31-35$ & 7 & $6.9 \%$ & $74.3 \%$ \\
\hline $36-40$ & 22 & $21.8 \%$ & $96.0 \%$ \\
\hline $41-46$ & 4 & $4.0 \%$ & $100.0 \%$ \\
\hline
\end{tabular}

Table 2. Marital status of the respondents

\begin{tabular}{|c|c|c|c|}
\hline $\begin{array}{c}\text { Marital status } \\
\text { Married }\end{array}$ & 27 & $26.7 \%$ & $26.7 \%$ \\
\hline Single & 74 & $73.3 \%$ & $100.0 \%$ \\
\hline $\begin{array}{c}\text { Level of education } \\
\text { Undergraduate }\end{array}$ & 38 & $37.6 \%$ & $37.3 \%$ \\
\hline Master Degree & 37 & $36.6 \%$ & $37.6 \%$ \\
\hline PhD & 26 & $25.7 \%$ & $100.0 \%$ \\
\hline
\end{tabular}

The target respondents picked the right answer to the question concerning the above-mentioned demographic measures. These variables were represented as follows:

a) Gender was coded as 17 females, 84 males.

b) Age was represented as 20-25 - 32; 26-30 - 36; 31-35 - 7; 36-40 - 22; 41-46- 4 .

c) Marital status was coded as follows: married 27, single 74.

d) Highest level of education was coded: university 38, master degree 37, $\mathrm{PhD} 26$.

e) The department of the respondents was coded as follows: Construction (17); Architecture (3); Consulting (4); Project manager (16); Project engineers (4); Engineers (53); and Surveyor (4).

\section{DATA ANALYSIS, RESULTS AND DISCUSSIONS}

\subsection{Reliability of the variable}

The reliability of the construct was tested using cronbanch Alpha. The accepted alpha value should exceed 0.7. As indicated in the Table 3, the cronbach Alpha value ranged from 0.772 to 0.888 , suggesting that the variables are reliable for the study.

Table 3. Cronbach Alpha value

\begin{tabular}{|c|c|}
\hline Variable & Cronbanch Alpha \\
\hline Management of Quality & 0.888 \\
\hline Implementation of Quality & 0.772 \\
\hline Cost of Quality o & $0 . .872$ \\
\hline
\end{tabular}

\subsection{Question: What is the perception of employees about the implementation of quality?}

The survey questionnaires were measured using a five Likert scale of three items (1-Strongly Disagree, 2Disagree, 3-Nuetral, 4 -Agree, 5-Strongly Agree) with 2.5 as the midpoint. Table 4 displays the mean and standard deviation (SD) scores on the perception of employees about the implementation of quality. The mean score of the three items ranged from 4.208 to 4.257 , suggesting that all the items greater than the midpoint of 2.5 .

This shows that the employees agreed with all the items. On the average (table 4), the employees have objectives and expectations of implementation of quality applications been achieved (M=4.257, SD=1.074), would you like to get the quality award and excellence $(\mathrm{M}=4.248, \mathrm{SD}=0.953)$ and believe that quality of your products match the quality of Foreign products $(\mathrm{M}=3.19$, $\mathrm{SD}=0.659$ ).

Table 4. Employees' perceptipn on implementation of quality

\begin{tabular}{|c|c|c|c|}
\hline Item & N & Mean & $\begin{array}{c}\text { Standard } \\
\text { Deviation }\end{array}$ \\
\hline $\begin{array}{c}\text { Do you Have the objectives and } \\
\text { expectations of Implementation } \\
\text { of quality applications been } \\
\text { achieved }\end{array}$ & 101 & 4.257 & 1.074 \\
\hline $\begin{array}{c}\text { Would you like to get the quality } \\
\text { award and excellence }\end{array}$ & 101 & 4.248 & 0.953 \\
\hline $\begin{array}{c}\text { The quality of your products } \\
\text { match the quality of Foreign } \\
\text { products }\end{array}$ & 101 & 4.208 & 1.061 \\
\hline
\end{tabular}

\subsection{Question: What is the perception of employees about the quality of cost?}

The survey questionnaires were measured using a five Likert scale of three items (1-Strongly Disagree, 2Disagree, 3-Nuetral, 4 -Agree, 5-Strongly Agree) with 2.5 as the midpoint. Table 5 presents the mean and 
standard deviation (SD) scores on the perception of employees about the quality of cost. The mean score of the three items ranged from 4.208 to 4.248 , indicating that all the items greater than the midpoint of 2.5. This suggests that the employees agreed with all the items.

On the average, the employees think the concept of quality cost in construction is unclear making the cost of quality failure relatively unknown during construction ( $M=4.218, S D=0.996)$, feel it is worth the effort to collect quality-related costs $(\mathrm{M}=4.208, \mathrm{SD}=0.864)$ and think that cost of failure during construction must be collected as soon as a failure occurs or at least on a weekly basis $(\mathrm{M}=4.248, \mathrm{SD}=0.876)$.

Table 5. Employees' perception on management of quality cost

\begin{tabular}{|c|c|c|c|}
\hline Item & N & Mean & $\begin{array}{c}\text { Standard } \\
\text { Deviation }\end{array}$ \\
\hline $\begin{array}{c}\text { Do you think the concept of quality } \\
\text { cost in construction is unclear making } \\
\text { the cost of quality failure relatively } \\
\text { unknown during construction }\end{array}$ & 101 & 4.218 & 0.996 \\
\hline $\begin{array}{c}\text { Do you feel it is worth the effort to } \\
\text { collect quality-related costs }\end{array}$ & 101 & 4.208 & 0.864 \\
\hline $\begin{array}{c}\text { Do you think Cost of failure during } \\
\text { construction must be collected as } \\
\text { soon as a failure occurs or at least on } \\
\text { a weekly basis }\end{array}$ & 101 & 4.248 & 0.876 \\
\hline
\end{tabular}

\subsection{Question: What is the perception of employees about the management of quality?}

The survey questionnaires were measured using a five Likert scale of three items (1-Strongly Disagree, 2Disagree, 3-Nuetral, 4 -Agree, 5-Strongly Agree) with 2.5 as the midpoint. Table 6 indicates the mean and standard deviation (SD) scores on the perception of employees about the management of quality. The mean score of the four items ranged from 4.208 to 4.356, showing that all the items greater than the midpoint of 2.5. This indicates that the employees agreed with all the items.

On the average, the employees think the important elements of quality in project management can help achieve project quality without incurring additional costs $(\mathrm{M}=4.208, \mathrm{SD}=0.816)$, think that in manufacturing, quality cost is most commonly categorized into prevention, appraisal and failure costs $(\mathrm{M}=4.218$, $\mathrm{SD}=0.867$ ), think that the concept of quality cost in construction is vague making the cost of quality failure relatively unknown during construction?

However quality cost is perceived as a useful indicator of performance $(\mathrm{M}=4.237, \mathrm{SD}=0.776)$, think that the concept of quality cost in construction is vague making the cost of quality failure relatively unknown during construction and however quality cost is perceived as a useful indicator of performance $(\mathrm{M}=4.356, \mathrm{SD}=0.855)$.
Table 6. Employees' perception on management of quality

\begin{tabular}{|c|c|c|c|}
\hline Item & N & Mean & $\begin{array}{l}\text { Standard } \\
\text { Deviation }\end{array}$ \\
\hline $\begin{array}{c}\text { Do you think the important elements of } \\
\text { quality in project management can help } \\
\text { achieve project quality without } \\
\text { incurring additional costs? }\end{array}$ & 101 & 4.208 & 0.816 \\
\hline $\begin{array}{c}\text { Do you think in manufacturing, quality } \\
\text { cost is most commonly categorized } \\
\text { into prevention, appraisal and failure } \\
\text { costs }\end{array}$ & 101 & 4.218 & 0.867 \\
\hline $\begin{array}{c}\text { Do you think the concept of quality } \\
\text { cost in construction is vague making } \\
\text { the cost of quality failure relatively } \\
\text { unknown during construction? } \\
\text { However quality cost is perceived as a } \\
\text { useful indicator of performance }\end{array}$ & 101 & 4.237 & 0.776 \\
\hline $\begin{array}{c}\text { Do you think the effect of collecting } \\
\text { quality costs on morale and attitude } \\
\text { and use of good project management } \\
\text { practices that will eventually create } \\
\text { opportunities for improvements in the } \\
\text { future }\end{array}$ & 101 & 4.356 & 0.855 \\
\hline
\end{tabular}

\subsection{Test of the Significance of Combined Factors}

The employees' responded data from the five point Likert scale items on the variables: Cost of Quality, Management of quality and Implementation of quality were aggregated and computed. This is to find their overall means and standard deviation as displayed in Table 7.

Cost of Quality of 4.277 ( $\mathrm{SD}=0.705)$ which shows that employees perceived cost of quality in construction organization is high. The mean for Management of Quality is 4.248 ( $\mathrm{SD}=0.932)$.

This indicates that the employees have positive perception about the management quality of construction organization. In addition, Implementation of quality recorded a high mean of $4.224(\mathrm{SD}=0.757)$ indicating that employees concern about implementation quality in construction organization, particularly in Libya.

Table 7. Employees' perception on management of quality

\begin{tabular}{|c|c|c|c|}
\hline Variable & Mean & Std. Deviation & Variance \\
\hline Cost of quality & 4.277 & 0.705 & 0.497 \\
\hline Mngt of quality & 4.248 & 0.932 & 0.868 \\
\hline Impl. of quality & 4.224 & 0.757 & 0.574 \\
\hline
\end{tabular}

Table 7 shows the Analysis of Variance (ANOVA) test of statistical significance of regression model and Table 8 indicates the standard regression model summary. From the ANOVA (Table 7), $\mathrm{F}=12.150$ and $\mathrm{p}=.000$ (< .05) which suggests that the test was statistically significant. 
This revealed that, the linear combination of independent variables (management and implementation quality) significantly relates to the cost of quality (dependent variables).

The standard regression model summary (Table 8) shows the value of the multiple correlation $(\mathrm{R}=0.446)$. This indicates how the combination of perceived management and implementation quality related to employees cost of quality. Furthermore, the Adjusted R2 $=0.182$ suggests that all the combination of perceived management and implementation quality contributes $18.2 \%$ of the variances in employees concern about cost of quality in construction organization (table 9).

Table 8. ANOVA of regression significant

\begin{tabular}{|c|c|c|c|c|c|c|}
\hline \multicolumn{2}{|c|}{ Model } & Sum of Squares & Df & Mean Square & F & Sig. \\
\hline \multirow{3}{*}{1} & Regression & 9.882 & 2 & 4.941 & 12.150 & $.000^{\mathrm{b}}$ \\
\cline { 2 - 8 } & Residual & 39.855 & 98 & .407 & & \\
\cline { 2 - 8 } & Total & 49.738 & 100 & & & \\
\hline
\end{tabular}

a. Dependent Variable: Cost_quality

b. Predictors: (Constant), Implementation of quality and Management of quality

Table 9. Standard regression model summary

\begin{tabular}{|c|c|c|c|c|c|c|c|c|c|}
\hline \multirow{2}{*}{ Model } & \multirow{2}{*}{$\mathbf{R}$} & R Square & \multirow{2}{*}{$\begin{array}{c}\text { Adjusted R } \\
\text { Square }\end{array}$} & $\begin{array}{c}\text { Std. Error } \\
\text { of the } \\
\text { Estimate }\end{array}$ & $\begin{array}{c}\text { R Square } \\
\text { Change }\end{array}$ & F Change & df1 & df2 & Sig. F Change \\
\hline 1 & $.446^{\mathrm{a}}$ & .199 & .182 & .63772 & .199 & 12.150 & 2 & 98 & .000 \\
\hline
\end{tabular}

a. Predictors: (Constant), Implementation_quality, Management_quality

\subsection{Test of the Significance of Individual Variables}

The significance of the individual variables was investigated using the regression coefficient (Beta weights) as displayed in Table 10. The independent variables management of quality $(\beta=0.220, \mathrm{t}=2.429, \mathrm{p}$ $=0.017<0.05)$ and implementation of quality $(\beta=0.398$, $\mathrm{t}=4.397, \mathrm{p}=0.000<0.05)$ were found to significant relate to the cost of quality.

Table 11 and Figure 4 indicate the parts and partial correlation of significant variable.

Table 10. The significance of the individual variables

\begin{tabular}{|c|c|c|c|c|c|c|c|c|c|}
\hline & \multirow[t]{2}{*}{ Model } & \multicolumn{2}{|c|}{$\begin{array}{l}\text { Unstandardized } \\
\text { Coefficients }\end{array}$} & \multirow{2}{*}{$\begin{array}{c}\begin{array}{c}\text { Standardize } \\
\text { d } \\
\text { Coefficients }\end{array} \\
\text { Beta } \\
\end{array}$} & \multirow[t]{2}{*}{$\mathbf{t}$} & \multirow[t]{2}{*}{ Sig. } & \multicolumn{2}{|c|}{ Collinearity Statistics } & \multirow{2}{*}{$\begin{array}{l}\text { Dubin- } \\
\text { Watson }\end{array}$} \\
\hline & & B & Std. Error & & & & Tolerance & VIF & \\
\hline \multirow{3}{*}{1} & (Constant) & 2.004 & .475 & & 4.224 & .000 & & & \\
\hline & $\begin{array}{c}\text { Management_q } \\
\text { uality }\end{array}$ & .166 & .069 & .220 & 2.429 & .017 & .998 & 1.002 & 1.889 \\
\hline & $\begin{array}{c}\text { Implementatio } \\
\text { n_quality }\end{array}$ & .371 & .084 & .398 & 4.397 & .000 & .998 & 1.002 & \\
\hline
\end{tabular}

a. Predictors: (Constant), Perceived Usefulness of Moodle, Perceived Challenges in using Moodle

b. Dependent Variable: Rate of Moodle Use

Table 11. Parts and partial correlation of significant variable

\begin{tabular}{|c|c|c|c|}
\hline \multirow{2}{*}{$\begin{array}{c}\text { Independent } \\
\text { Variable }\end{array}$} & \multicolumn{3}{|c|}{ Correlations } \\
\cline { 2 - 4 } & Zero-order & Partial & Part \\
\hline $\begin{array}{c}\text { Management of } \\
\text { quality }\end{array}$ & .201 & .238 & .220 \\
\hline $\begin{array}{c}\text { Implementation } \\
\text { of quality }\end{array}$ & .388 & .406 & .398 \\
\hline
\end{tabular}

Zero-order correlation is the correlation coefficients of the variable individually with the dependent variable (cost of quality). The part-squared values show the contribution of individual variables of the overall fit of the regression model. Implementation of quality is the most important variable for predicting the cost of quality by contributing $39.8 \%$ (Part-Square $=.0807$ ).
Management of quality contributed $22.0 \%$ (Part-Square $=.0243$ ) to the value cost of quality in construction organization.

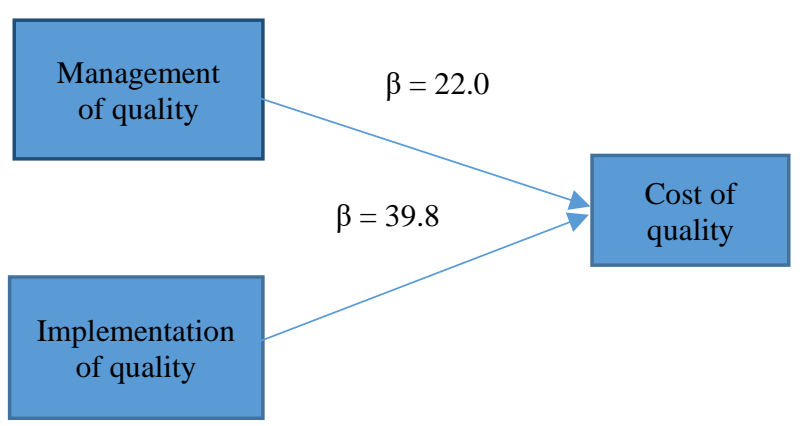

Figure 4. Result of research model 


\section{LIMITATIONS}

First, despite efforts to have many female respondents in the study, only $16.8 \%$ took part in the actual research. This is because of the current situation in Libya which has forced many people especially women to remain at home for safety reasons.

Prevailing organizational culture has created many gaps that fail to support the application of total quality management system. Thus, many respondents had little or no knowledge on quality management systems implemented in their organizations.

\section{CONCLUSION}

The main objective of this research study is to investigate the effect of management style on the cost of quality, using case studies of Misrat Cement Factory, and Dana Libyan Korean Construction Company in Tripoli, LIBYA.

To achieve this, it becomes necessary to take the basic steps towards achieving that set objectives by identifying the primary drivers of quality and challenges encountered in terms of quality cost by gathering information from the respondents or targeted audience in this research study.

The result of this research has proven that the use of cost of quality concepts improves the construction process in general. Furthermore, it was also discovered from this study that adhering to quality implementation procedures does not affect the construction process, or deter it from normal operations.

However, it is important to note that management style has a direct effect on the cost of quality.

The objectives of the research were measured with the questionnaire and tied to the hypotheses, responses from the respondents were analyzed which were used to deduce the above conclusions.

\section{RECOMMENDATIONS}

Improved government policies will help create awareness on the benefits of incorporating quality cost initiatives as part of companies' project practices.

While implementing quality cost strategies, proper training should be carried out to ensure effectiveness.

Quality management should be an integral part of the quality cost concept in engineering firms and projects as they are the main principal drivers of the cost of quality.

Cost of quality should be defined clearly by organizations, as this has been a root cause for challenges in engineering and construction projects.

Government or its bodies should ensure that a certain level of quality is met by all construction firms. This can be done by putting in place and enforcing standards and practices.

\section{References:}

Afshar, A., Kaveh, A., \& Shoghli, O. R. (2007). Multi-objective optimization of time-cost-quality using multi-colony ant algorithm. Asian Journal of Civil Engineering, 8(2), 113-124.

Aized, T. (2012). Total Quality Management and Six Sigma. Rijeka, Croatia: InTech. ISBN 978-953-51-0688-3

Alberto, D. M. (2011). Project Management for Facility Constructions: A Guide for Engineers and Architects. Heidelberg. New York: Springer-Verlag. ISBN 978-3-642-17091-1

Ali, A., \& Rahmat, H. (2010). The performance measurement of construction projects managed by ISO-certified contractors in Malaysia. Journal of Retail \& Leisure Property, 9(1), 25-35.

Caldwell, J. A., \& Hagen, T. D. (1994). Engineering Consultants Implement TQM. Quality Progress, 27(1), 57-63.

Crosby, P. B. (1979). Quality Is Free: The Art of Making Quality Certain. New York: McGraw-Hill.

Deming, W. E. (1986). Out of the Crisis: Quality, Productivity, and Competitive Position. Cambridge, MA: Cambridge University Press.

Enshassi, A., Arain, F., \& El-Rayyes, Y. (2014). Post-evaluation System in Construction Projects in Gaza Strip Palestine. Journal of Construction in Developing Countries, 19(2), 51-73.

Fan, M., Lin, N., \& Sheu, C. (2008). Choosing a project risk-handling strategy: An analytical model. International Journal of Project Management, of the market, 112, 700-713.

Feigenbaum, A. (1991). Total Quality Control (3rd ed.). New York: McGraw-Hill.

Hilton, R., Maher, M., \& Selto, F. (2008). Cost Management, Strategies for Business Decision (3rd ed.). Irwin/McGrawHill.

Hokoma, R. A., Khan, M. K., \& Hussain, K. (2008). An investigation of Total Quality Management implementation status for the Oil and Gas industry in Libya. Paper presented in Quality Congress Middle East 2, 2008, Dubai. 
Kerzner, H. (2010). Project Management: A Systems Approach to Planning, Scheduling, and Controlling (10th ed.). Hoboken, New Jersey: John Wiley \& Sons, Inc. ISBN 978-0-470-27870-3.

Khattak, A., \& Arshad, M. (2015). Barricades in Implementation and Adoptation Level of ISO-9001 in Construction Industry of Pakistan. European Journal of Business and Management, 7(13), 203-211.

Madsen, S. (2013). Is the iron triangle outdated? Retrieved from http://www.susannemadsen.co.uk/blog/the-irontriangleand-the-tripleconstraintsare-outdated (Accessed on December 12, 2013).

Mane, P., \& Patil J. (2015). Quality Management System at Construction Project: A Questionnaire Survey. Journal of Engineering Research and Applications, 5(3), 126-130.

Natarajan, D. (2017). ISO 9001 Quality Management Systems. Bangalore: Springer International Publishing.

Neyestani, B., \& Juanzon, J. B. P. (2016). Identification of A Set of Appropriate Critical Success Factors for Successful TQM Implementation in Construction, and Other Industries. International Journal of Advanced Research, 4(11), 15811591.

O’Neill, P., Sohal, A., \& Teng, C. W. (2016). Quality management approaches and their impact on firms' financial performance: An Australian study. International Journal of Production Economics, 171(3), 381-393.

Perkowski, J.C. (1988) Technical Trends in the E\&C business: the next 10 years. Journal of Construction Management and Engineering, 114(4), 565-76.

Rahnamayroodposhti, F. (2008). Strategic Management Accounting: Creating Value Cost Management Emphasis: Science and Research branch. Islamic Azad University, Tehran, Iran.

Ross, J. E. (1999). Total Quality Management. Florida: CRC Press LLC.

Schmidt, W. D., \& Rieck, D. A. (2000). Managing Media Services. Colorado: Libraries Unlimited.

Stevens, T. (1994). Dr. Armand Feigenbaum on the Cost of Quality and the Hidden Factory. Retrieved from https://www.industryweek.com/quality/dr-armand-feigenbaum-cost-quality-and-hidden-factory

Zhou, B. (2012). Lean principles, practices, and impacts: a study on small and medium-sized enterprises (SMEs). Annals of Operations Research, 241(1-2), 457-474.

Zimak, G. (2000). Cost of Quality (COQ): Which collection system should be used? ASQ's 54th Annual Quality Congress Proceedings, 18-24.

Hamza Ali. K. Krebish

Cyprus International University, Business Administration Department, Nicosia, North Cyprus, Mersin 10, Turkey

Ang.ly80@yahoo.com

\author{
Aysen Berberoglu \\ Cyprus International University, \\ Business Administration Department, \\ Nicosia, North Cyprus, Mersin 10, \\ Turkey \\ Aysen.berberoglu@gmail.com
}

